\title{
Pengembangan Sistem Informasi Pariwisata Terintegrasi E-Ticket Mobile dengan Metode Extreme Programming (Studi Kasus Dinas Pariwisata Karangasem)
}

\author{
Ida Bagus Prayoga Bhiantara ${ }^{1}$, Gede Indrawan ${ }^{2}$, Kadek Yota Ernanda Aryanto $^{3}$ \\ 1,2,3 Magister Ilmu Komputer, Universitas Pendidikan Ganesha \\ Jl. Udayana No.11, Banyuasri, Kec. Buleleng, Kab. Buleleng, Bali \\ 1'gusss.yoga@gmail.com, ${ }^{2}$ gindrawan@undiksha.ac.id, ${ }^{3}$ yota.ernanda@undiksha.ac.id
}

Diterima : 31 Agustus 2021

Disetujui : 28 September 2021

\begin{abstract}
Pariwisata merupakan suatu kegiatan dilakukan oleh manusia secara kelompok maupun perorangan untuk mengunjungi tempat yang menarik didalam wilayah suatu negara sendiri atau negara lain. Kabupaten Karangasem merupakan salah satu kabupaten di Bali yang memiliki banyak tempat wisata menjadi daerah yang cukup sering dikunjungi wisatawan. Namun pendataan tempat wisata oleh Dinas Pariwisata masih dilakukan secara konvensional sehingga diperlukan pegawai serta waktu untuk melakukan pendataan tehadap tiket tempat wisata. Untuk itu dilakukan pengembangan "Sistem Informasi Pariwisata Terintegrasi E-Ticket Mobile dengan Metode Extreme Programming". Metode Extreme Programming merupakan metode yang mengutamakan kecepatan sehingga sangat cocok untuk digunakan mengingat kebutuhan saat ini diperlukan pengembangan sistem yang mengharuskan cepat dan akurat. Metode ini memiliki 4 tahapan yaitu perencanaan, desain, penulisan code dan pengujian. Pada pengujian black box, output yang dihasilkan sistem sudah berfungsi sesuai dengan harapan. Dari pengujian running time menunjukan rata-rata waktu menyelesaikan setiap proses adalah $479 \mathrm{~ms}$. Pada pengujian respon pengguna menunjukan sistem dapat digunakan dengan baik.
\end{abstract}

Keywords - Integration System, Mobile, Web, Extreme Programming

\section{PENDAHULUAN}

Bangsa Indonesia merupakan bangsa yang memiliki banyak keragaman, baik dari segi adat, budaya, agama, suku dan bahasa sehingga negara Indonesia adalah negara yang kaya akan sumber daya alamnya. Sumber daya alam tersebut jika dikelola dengan baik dapat dijadikan sebagai potensi untuk memakmurkan rakyat dan memajukan bangsa Indonesia. Salah satunya yang dapat dikembangkan adalah dalam bidang kepariwisataan. Seiring berjalannya waktu, pariwisata di Indonesia saat ini telah tumbuh dan berkembang dengan baik[1].

Perkembangan pariwisata untuk daerahdaerah pariwisata di Indonesia menjadi salah satu sektor pemasukan dalam penghasilan daerah maupun pendapatan untuk devisa negara[2]. Negara Indonesia sangat terkenal dengan keindahan sektor pariwisatanya sehingga sampai saat ini sektor pariwisata masih menjadi perhatian penting oleh pemerintah untuk terus dikembangkan. Terkait dengan sektor pariwisata dalam Undang-Undang Republik Indonesia No 9 Tahun 1990 menyatakan bahwa pariwisata mempunyai peran dalam memberikan lapangan kerja, meningkatkan pembangunan daerah dan penghasilan negara, mengembangkan kebudayaan nasional serta pembinaannya dalam rangka memperkukuh jati diri bangsa dan persahabatan antar bangsa[3]. 
Provinsi Bali sampai saat ini masih menjadi daerah utama kunjungan oleh wisatawan mancan negera, salah satu kabupaten di Bali yaitu kabupaten Karangasem memiliki cukup banyak tempat wisata yang sangat indah, selain itu juga terdapat banyak Pura besar seperti Pura Besakih, Pura Lempuyang, Pura Andakasa dan Pura-Pura besar lainnya sehingga karangasem juga merupakan tujuan wisata religius kususnya untuk pemeluk agama Hindu. Namun saat ini pendataan untuk tempat wisata oleh Dinas Pariwisata di kabupaten Karangasem masih dilakukan secara konvensional sehingga diperlukan tenaga serta waktu yang cukup banyak. Pelayanan pembelian tiket juga masih dilakukan secara manual. Tiket yang akan dijual kepada wisatawan sudah dipersiapkan terlebih dahulu dengan mencetak sejumlah lembaran beserta nomer seri tiket. Jika terjadi kehilangan salah satu lembaran tiket, hal tersebut harus dipertanggungjawabkan. Terlebih lagi biaya untuk mencetak tiket dengan jumlah besaran yang telah ditentukan tentunya kurang efisien. Terdapat besaran biaya yang mengendap karena tiket harus menunggu habis terjual.

Tujuan penelitian ini adalah mengembangkan sebuah sistem informasi pariwisata yang dapat terintegrasi dengan aplikasi e-ticket untuk mengatasi permasalahan yang terjadi pada proses penjualan tiket di tempat wisata serta kesalahan pelaporan tiket karena kurang akuratnya data penjualan tiket di tempat wisata. Dengan adanya pengembangan yang terintegrasi seperti ini dapat memudahkan bagi petugas di tempat wisata dalam melaporkan hasil penjualan tiket serta mengatasi permasalahan tiket yang tidak terjual, sehingga dapat mengurangi biaya yang harus dikeluarkan dalam penjualan tiket masuk di tempat wisata dan akan membantu pelaporan tiket yang terjual menjadi lebih cepat dan akurat secara realtime.

\section{METODE PENELITIAN}

Metode Extreme Programming adalah sebuah paradigma pembangunan mencakup seperangkat aturan dan praktik yang terjadi dalam konteks kerangka empat kegiatan yaitu: perencanaan, desain, coding, dan pengujian. Keempat aktivitas inilah yang akan menghasilkan sebuah perangkat lunak yang didasari dengan konsep model Extreme Programming[4]. Dapat dilihat pada gambar 1

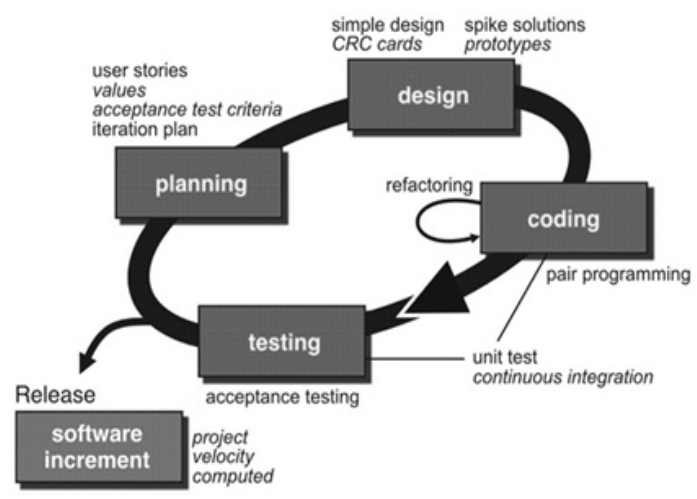

Gambar 1. Metode Extreme Programing (Sumber: http://www.thedynamicdomain.com/ extremeprogramming.aspx)

Dasar dari metode Extreme Programming ini adalah metode pengembangan perangkat lunak yang berfokus pada fitur dan kecepatan dalam membangun sebuah perangkat lunak[5]. Dalam metode Extreme Programming terdapat tahapantahapan yang berurutan dimulai dari Perencanaan Sistem, Desain Sistem, Penulisan Code, serta Pengujian System[6]. Metode Extreme Programming sangat cepat dalam mengembangkan perangkat lunak, tidak ada metodologi lain yang dapat disarankan paling cocok dalam semua skenario pengembangan perangkat lunak[7]. Metode Extreme Programming memberikan hasil yang lebih baik dengan penyelesaian yang sangat cepat dan pengurangan risiko dalam pengembangan aplikasi[8].

Tahap pertama dari penelitian ini yaitu Tahap Perencanaan. Pada tahap ini dilakukan pengumpulan data dengan melakukan wawancara dengan kepala Dinas Pariwisata Kabupaten Karangasem. Dilanjutkan dengan melakukan observasi pada lokasi wisata dan terahir dilakukan analisis kebutuhan fungsional dan non fungsional. Dari tahap perencanaan akan dilanjutkan tahap berikutnya yaitu tahap desain system. Pada tahap ini dilakukan desain sistem dengan diagram UML yang terdiri dari use case diagram, activity diagram, dan design interface 
system[9]. Setelah tahap desain system dilanjutkan pada tahapan penulisan code. Tahap ini akan mengimplementasikan bentuk rancangan pada tahap desain system kedalam bentuk code program yang kemudian akan dicompiler menjadi sebuah prototipe sistem. Pada tahap konfigurasi produk dan generasi, prototipe sistem diuji menggunakan metode black box, instrument pengguna dan running time. Jika dalam pengujian terdapat revisi, maka dilakukan konfigurasi dan diuji kembali hingga hasilnya sesuai dengan yang diharapkan. Setelah prototipe lulus pengujian, dilakukan analisis hasil uji dan penarikan kesimpulan.

Alur dari tahapan kerangka penelitian pengembangan sistem ini, berdasarkan menggunakan metode Extreme Programing dapat dilihat pada gambar 2 .

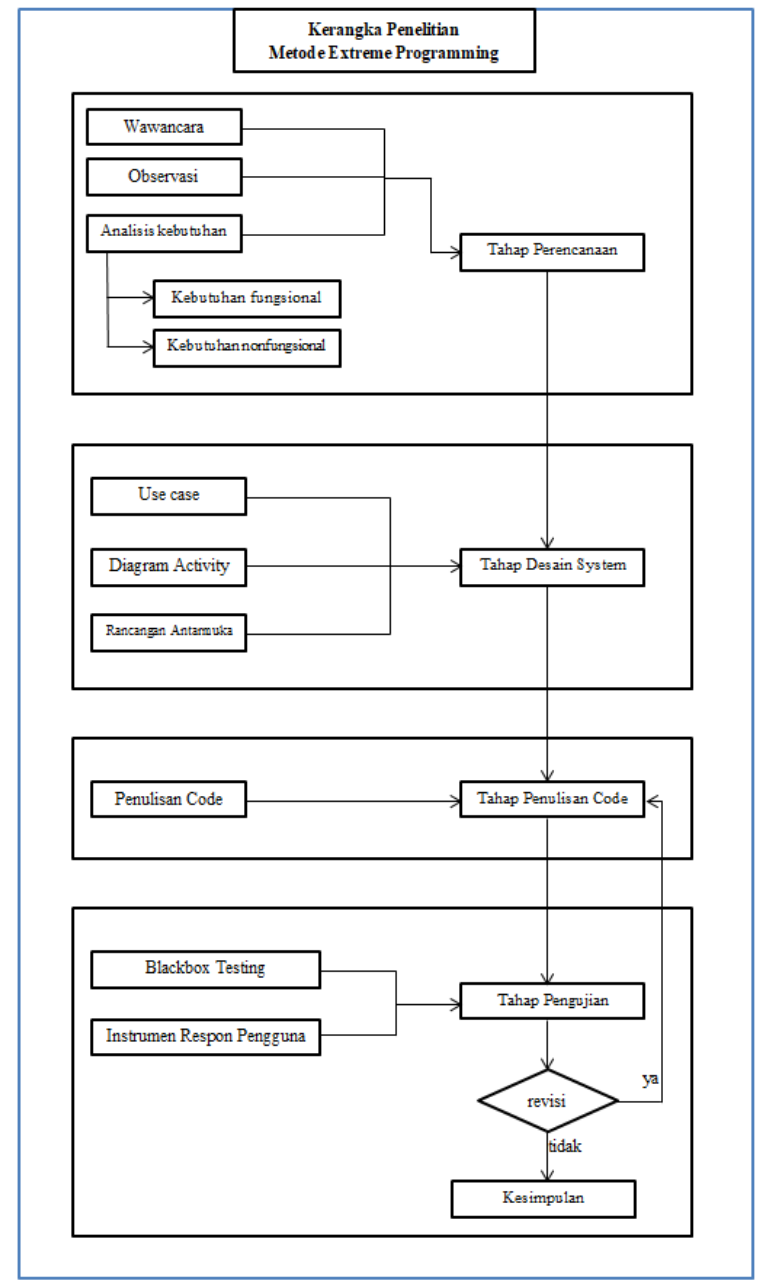

Gambar 2. Kerangka Penelitian dengan Metode Extreme Programing

\section{A. Tahap Perencanaan (Planning)}

Pada tahap perencanaan merupakan analisis kebutuhan untuk pengembangan aplikasi. Pengumpulan data dilakukan untuk menentukan spesifikasi fitur dari aplikasi agar dapat disesuaikan dengan keadaan di lapangan sehingga perlu dilakukan beberapa tahap pengumpulan data. Adapun tahapan pengumpulan data yang dilakukan yaitu wawacara dilakukan dengan kepala dinas kabupaten karangasem untuk mengumpulkan data-data yang dibutuhkan seperti spesifikasi aplikasi yang diinginkan serta fitur-fitur yang akan ada pada aplikasi. Kemudian observasi langsung dilakukan untuk mengetahui keadaan tempat wisata yang akan menggunakan aplikasi, serta melakukan observasi terhadap sumber daya terkait dengan koneksi jaringan dan perangkat yang akan dijalankan pada tempat wisata. Analisis kebutuhan meliputi Kebutuhan Fungsional berisi proses-proses yang dapat dilakukan oleh system serta berisi informasi fungsional dari menu pada system. Analisis kebutuhan non fungsional adalah perangkat keras yang dibutuhkan untuk memenuhi kebutuhan fungsional dari system. Sehingga untuk dapat menjalankan system dengan baik diperlukan spesifikasi perangkat yang sesuai dengan fungsional dari system maupun aplikasi.

\section{B. Tahap Desain System (Design)}

Proses desain system merupakan tahap setelah melakukan perencanaan yang meliputi wawancara, observasi dan mendefinisikan kebutuhan kemudian dilanjutkan dengan tahap membuat rancangan desain dari system. Perancangan desain system meliputi mendefinisikan fitur yang diimplementasi dan input atau output yang dihasilkan oleh sistem. Proses desain dilakukan dengan membuat diagram UML yang terdiri dari Use Case Diagram, Activity Diagram dan Design Interface System. Dari tahap ini menghasilkan desain sistem yang nantinya diwujudkan dalam bentuk prototype pada tahap penulisan code. 


\section{Tahap Penulisan Code (Coding)}

Tahap penulisan kode merupakan implementasi dari tahap perancangan system. Penulisan kode dilakukan dengan menguraikan rancangan yang sudah disepakati ke dalam bentuk kode program. Selanjutnya implementasi akan dimulai dengan membuat kode untuk tampilan system, kemudian dilanjutkan penulisan code untuk logic setiap tombol aksi di halaman sistem. Setiap proses akan diimplementasikan kedalam bentuk class-class objek yang disesuaikan dengan fitur pada tahap perencanaan sistem. Setelah penulisan code setiap class selesai dilanjukan dengan melakukan compiler pada code program yang kemudian akan menghasilkan sebuah aplikasi dalam bentuk prototype.

\section{Tahap Pengujian (Testing)}

Pada saat program selesai dibuat, pengujian program dimulai. Proses pengujian difokuskan pada logika internal perangkat lunak, mamastikan bahwa semua pernyataan sudah diuji dan pada eksternal fungsional yaitu mengarahkan pengujian untuk menemukan kesalahankesalahan dan memastikan bahwa input yang dibatasi akan memberikan hasil aktual yang sesuai dengan hasil yang dibutuhkan. Proses pengujian dilakukan dengan menginstal aplikasi ini langsung ke perangkat Android. Blackbox testing adalah pengujian yang dilakukan dengan cara mengamati hasil eksekusi melalui data uji dan memeriksa kesesuian fitur-fitur dari system dengan menggunakan intrumen fungsional[10]. Pengujian terhadap respon pengguna merupakan instrumen yang diberikan untuk mengetahui respon dari pengguna terhadap system.

\section{HASIL DAN PEMBAHASAN}

\section{A. E-Ticket Mobile}

E-Ticket Mobile merupakan aplikasi mobile android yang terintegrasi dengan Sistem Informasi Pariwisata. Aplikasi e-ticket mobile memiliki beberapa menu utama yang dapat digunakan oleh petugas di tempat wisata. Ada 9 menu utama yaitu Login, Home, E-ticket,
Pengumuman Option, About Profile dan Logout. Kemampuan aplikasi untuk dapat berinteraksi dengan pengguna digambarkan dalam use case diagram dapat dilihat pada gambar 3 .

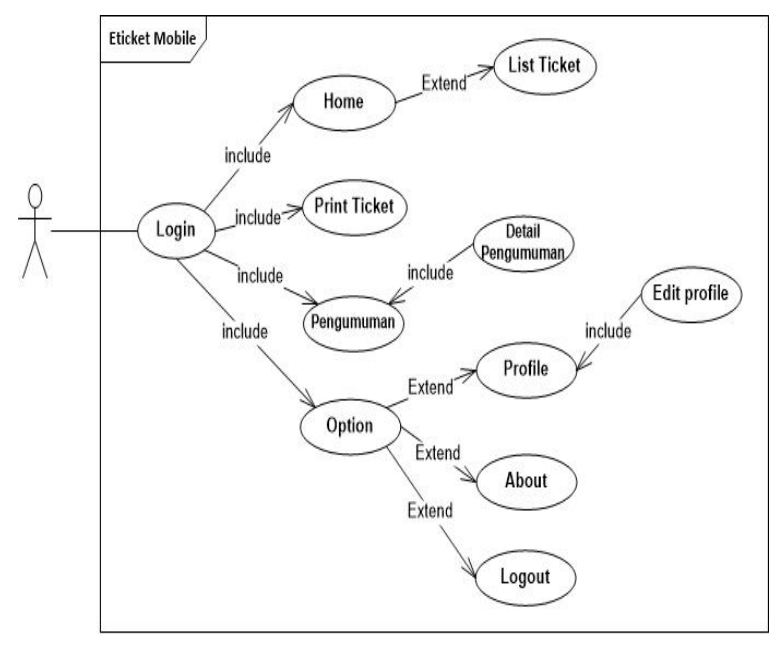

Gambar 3. Diagram Use Case E-Ticket Mobile

Fungsi setiap menu pada aplikasi E-Ticket Mobile dapat di lihat pada tabel 1.

Tabel 1 Fitur aplikasi E-Ticket Mobile

\begin{tabular}{|c|c|c|}
\hline No & Fitur & Penjelasan \\
\hline 1 & Menu Login & Autentikasi data pengguna. \\
\hline 2 & Menu Home & $\begin{array}{lr}\text { Digunakan } & \text { untuk } \\
\text { memampilkan data } \\
\text { singkat petugas yang } \\
\text { login }\end{array}$ \\
\hline 3 & $\begin{array}{l}\text { Menu Lihat } \\
\text { Tiket }\end{array}$ & $\begin{array}{l}\text { Digunkan untuk melihat } \\
\text { jumlah tiket terjual, dan } \\
\text { melihat list tiket yang belum } \\
\text { disyncron }\end{array}$ \\
\hline 4 & $\begin{array}{l}\text { Menu Print } \\
\text { Tiket }\end{array}$ & $\begin{array}{l}\text { Digunakan petugas untuk } \\
\text { mencentak tiket dan } \\
\text { melakukan syncron data tiket } \\
\text { terjual ke server }\end{array}$ \\
\hline 5 & $\begin{array}{l}\text { Menu } \\
\text { Pengumuman }\end{array}$ & $\begin{array}{l}\text { Digunakan petugas untuk } \\
\text { menampilkan } \\
\text { pengumuman yang telah } \\
\text { dibuat oleh operator pada } \\
\text { server }\end{array}$ \\
\hline
\end{tabular}




\begin{tabular}{|l|l|l|}
\hline No & Fitur & Penjelasan \\
\hline 6 & Menu Option & $\begin{array}{l}\text { Digunakan untuk } \\
\text { menampilkan sub menu } \\
\text { profile, about dan logout }\end{array}$ \\
\hline 7 & Menu Profile & $\begin{array}{l}\text { Digunakan untuk } \\
\text { menampilkan profile serta } \\
\text { petugas perubahan data }\end{array}$ \\
\hline 9 & Menu About & $\begin{array}{l}\text { Digunakan } \\
\text { menampilkan info aplikasi, } \\
\text { tanggal pembuatan serta } \\
\text { tanggal update. }\end{array}$ \\
\hline & Menu Logout & $\begin{array}{l}\text { Digunakan untuk melakukan } \\
\text { logout pengguna pada } \\
\text { aplikasi pengguna } \\
\text { dari aplikasi. }\end{array}$ \\
\hline
\end{tabular}

Berikut gambar 4 merupakan tampilan halaman menu utama dari aplikasi E-Ticket Mobile.

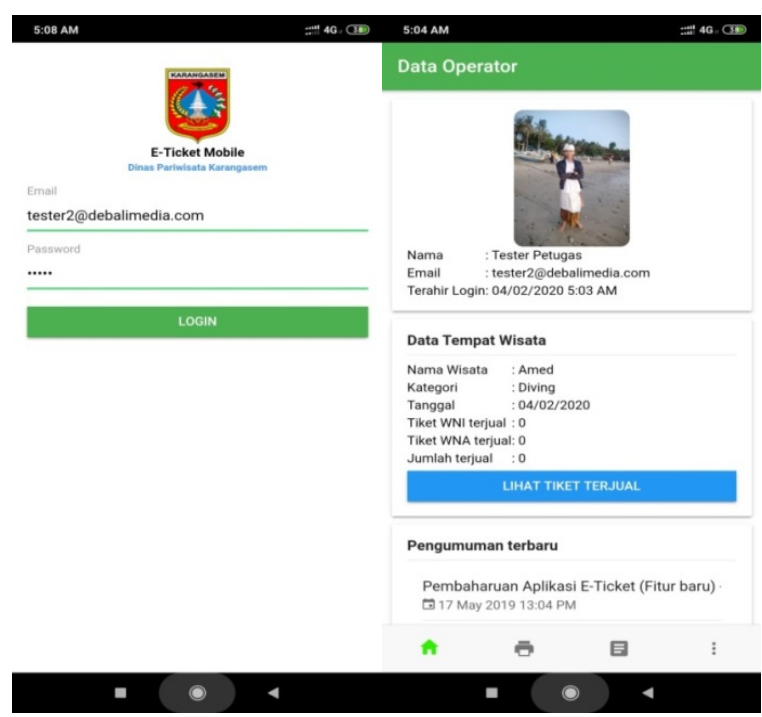

Gambar 4. Implementasi E-Ticket Mobile

\section{B. Sistem Informasi Pariwisata}

Sistem Informasi Pariwisata merupakan aplikasi yang berbasis web yang digunakan untuk mendata tempat objek wisata. Sistem Informasi Pariwisata memiliki beberapa menu utama yang dapat digunakan oleh petugas tempat wisata. Sistem akan memiliki 21 menu utama yaitu Dashboard, Pengelola, Hak Akses, Pengumuman, Data Wisata, Data Penginapan, Data Tempat Makan, Jenis Wisata, Jenis Pengnapan, Wilayah dan Laporan. Kemampuan sistem untuk dapat berinteraksi dengan pengguna digambarkan dalam use case diagram dapat dilihat pada gambar 5 .

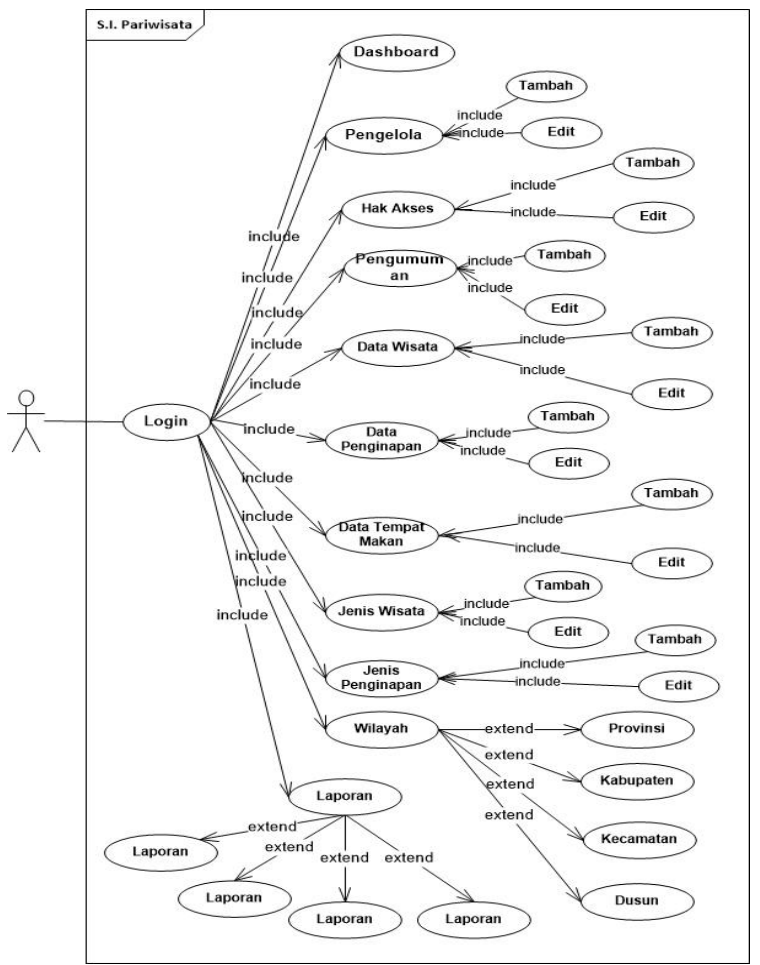

Gambar 5. Diagram Use Case Sistem Informasi Pariwisata

Fungsi setiap menu pada sistem informasi pariwisata dapat di lihat pada tabel 2 .

Tabel 2 Fitur Sistem Informasi Pariwisata

\begin{tabular}{|c|l|l|}
\hline No & \multicolumn{1}{|c|}{ Fitur } & \multicolumn{1}{c|}{ Penjelasan } \\
\hline 1 & Menu Login & Autentikasi data pengguna. \\
\hline 2 & $\begin{array}{l}\text { Menu } \\
\text { Dashboard }\end{array}$ & $\begin{array}{l}\text { Digunakan untuk } \\
\text { menampilkan halaman } \\
\text { dashboard pada web }\end{array}$ \\
\hline 3 & $\begin{array}{l}\text { Menu } \\
\text { Pengelola }\end{array}$ & $\begin{array}{l}\text { Digunakan untuk } \\
\text { menampilkan halaman } \\
\text { pengelola serta } \\
\text { menambahkan pengguna } \\
\text { pengelola tempat wisata }\end{array}$ \\
\hline
\end{tabular}




\begin{tabular}{|c|c|c|}
\hline No & Fitur & Penjelasan \\
\hline 4 & $\begin{array}{l}\text { Menu Hak } \\
\text { Akses }\end{array}$ & $\begin{array}{l}\text { Digunakan untuk } \\
\text { menampilkan halaman hak } \\
\text { akses serta mengatur hak } \\
\text { akses pegawai. }\end{array}$ \\
\hline 5 & $\begin{array}{l}\text { Menu } \\
\text { Pengumuman }\end{array}$ & $\begin{array}{l}\text { Digunakan untuk } \\
\text { menampilkan halaman } \\
\text { pengumuma serta membuat } \\
\text { pengumuman untuk } \\
\text { ditampilkan pada aplikasi } \\
\text { E-Ticket Mobile }\end{array}$ \\
\hline 6 & $\begin{array}{l}\text { Menu Data } \\
\text { Wisata }\end{array}$ & $\begin{array}{l}\text { Digunakan untuk } \\
\text { menampilkan halaman Data } \\
\text { Wisata serta menambakan } \\
\text { Data Wisata baru. }\end{array}$ \\
\hline 7 & $\begin{array}{l}\text { Menu Data } \\
\text { Penginapan }\end{array}$ & $\begin{array}{l}\text { Digunakan untuk } \\
\text { menampilkan halaman Data } \\
\text { Penginapan serta } \\
\text { menambahkan Data } \\
\text { Penginapan baru. }\end{array}$ \\
\hline 8 & $\begin{array}{l}\text { Menu Tempat } \\
\text { Makan }\end{array}$ & $\begin{array}{l}\text { Digunakan untuk } \\
\text { menampilkan halaman } \\
\text { Tempat Makan serta } \\
\text { menambahkan Data Tempat } \\
\text { Makan. }\end{array}$ \\
\hline 9 & $\begin{array}{l}\text { Menu Jenis } \\
\text { Wisata }\end{array}$ & $\begin{array}{l}\text { Digunakan untuk } \\
\text { menampilkan halaman Jenis } \\
\text { Wisata serta menambahkan } \\
\text { master Jenis Wisata. }\end{array}$ \\
\hline 10 & $\begin{array}{l}\text { Menu Jenis } \\
\text { Penginapan }\end{array}$ & $\begin{array}{l}\text { Digunakan untuk } \\
\text { menampilkan halaman Jenis } \\
\text { Penginapan serta } \\
\text { menambahkan master Jenis } \\
\text { Penginapan. }\end{array}$ \\
\hline 11 & $\begin{array}{l}\text { Menu } \\
\text { Wilayah } \\
\text { Provinsi }\end{array}$ & $\begin{array}{l}\text { Digunakan untuk } \\
\text { menampilkan halaman } \\
\text { Wilayah Provinsi serta } \\
\text { menambahkan master } \\
\text { Provinsi. }\end{array}$ \\
\hline 12 & $\begin{array}{l}\text { Menu } \\
\text { Wilayah } \\
\text { Kabupaten }\end{array}$ & $\begin{array}{l}\text { Digunakan untuk } \\
\text { menampilkan halaman } \\
\text { Wilayah Kabupaten serta } \\
\text { menambahkan master }\end{array}$ \\
\hline
\end{tabular}

\begin{tabular}{|c|c|c|}
\hline No & Fitur & Penjelasan \\
\hline & & Kabupaten. \\
\hline 13 & $\begin{array}{l}\text { Menu } \\
\text { Wilayah } \\
\text { Kecamatan }\end{array}$ & $\begin{array}{l}\text { Digunakan untuk } \\
\text { menampilkan halaman } \\
\text { Wilayah Kelurahan serta } \\
\text { menambahkan master } \\
\text { Kecamatan. }\end{array}$ \\
\hline 14 & $\begin{array}{l}\text { Menu } \\
\text { Wilayah } \\
\text { Kelurahan }\end{array}$ & $\begin{array}{l}\text { Digunakan untuk } \\
\text { menampilkan halaman } \\
\text { Wilayah Kelurahan serta } \\
\text { menambahkan master } \\
\text { Kelurahan. }\end{array}$ \\
\hline 15 & $\begin{array}{l}\text { Menu } \\
\text { Wilayah } \\
\text { Dusun }\end{array}$ & $\begin{array}{l}\text { Digunakan untuk } \\
\text { menampilkan halaman } \\
\text { Wilayah Dusun serta } \\
\text { menambahkan master } \\
\text { Dusun. }\end{array}$ \\
\hline 16 & $\begin{array}{l}\text { Menu } \\
\text { Laporan } \\
\text { Tempat } \\
\text { Wisata }\end{array}$ & $\begin{array}{l}\text { Digunakan untuk mencetak } \\
\text { laporan tempat wisata pada } \\
\text { web }\end{array}$ \\
\hline 17 & $\begin{array}{l}\text { Menu } \\
\text { Laporan } \\
\text { Tempat } \\
\text { Peginapan }\end{array}$ & $\begin{array}{l}\text { Digunakan untuk mencetak } \\
\text { laporan tempat Penginapan } \\
\text { pada web }\end{array}$ \\
\hline 18 & $\begin{array}{l}\text { Menu } \\
\text { Laporan } \\
\text { Tempat } \\
\text { Makan }\end{array}$ & $\begin{array}{l}\text { Digunakan untuk mencetak } \\
\text { laporan tempat Makan pada } \\
\text { web }\end{array}$ \\
\hline 19 & $\begin{array}{l}\text { Menu } \\
\text { Laporan } \\
\text { Transaksi } \\
\text { Tiket }\end{array}$ & $\begin{array}{l}\text { Digunakan untuk mencetak } \\
\text { laporan Transaksi Tiket di } \\
\text { tempat wisata pada website }\end{array}$ \\
\hline 20 & $\begin{array}{l}\text { Menu } \\
\text { Notifikasi } \\
\text { Perubahan } \\
\text { Data }\end{array}$ & $\begin{array}{l}\text { Digunakan untuk menampilkan } \\
\text { Notifikasi perubahan data untuk } \\
\text { user Admin }\end{array}$ \\
\hline 21 & Menu Logout & $\begin{array}{l}\text {-Digunakan untuk melakukan } \\
\text { logout pengguna pada } \\
\text { aplikasi }\end{array}$ \\
\hline
\end{tabular}


Ida Bagus Prayoga Bhiantara, Gede Indrawan, Kadek Yota Ernanda Aryanto

\begin{tabular}{|l|l|l|}
\hline No & Fitur & \multicolumn{1}{c|}{ Penjelasan } \\
\hline & & $\begin{array}{l}\text {-Menghapus sesi pengguna dari } \\
\text { aplikasi. }\end{array}$ \\
\hline
\end{tabular}

Berikut gambar 6 merupakan tampilan menu utama dari aplikasi Sistem Informasi Pariwisata

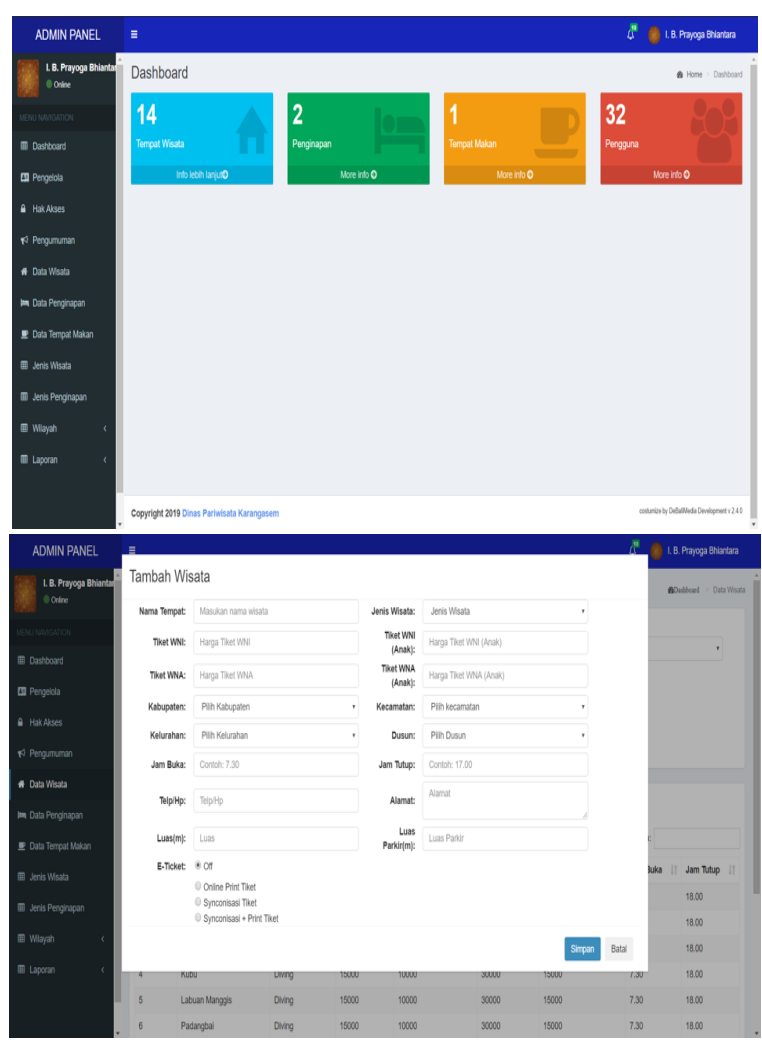

Gambar 6. Sistem Informasi Pariwisata

\section{Hasil Pengujian}

Pada pengujian blackbox, prototype dari sistem telah menghasilkan output yang sesuai dengan harapan dari skenario yang diujikan. Berikut hasil pengujian blackbox dapat dilihat pada tabel 3 .

Tabel 3. Hasil Pengujian BlackBox

\begin{tabular}{|c|c|c|}
\hline \multicolumn{2}{|c|}{ Kasus Dan Hasil Uji (Data Normal) } \\
\hline \multirow{2}{*}{ Aktivitas Pengujian } & \multicolumn{2}{|c|}{ Kesimpulan } \\
\cline { 2 - 3 } & Terima & Tolak \\
\hline Klik Menu Dashboard & Iya & \\
\hline
\end{tabular}

\begin{tabular}{|c|c|}
\hline Klik Menu Pengelola & Iya \\
\hline Klik Menu Hak Akses & Iya \\
\hline Klik Menu Pengumuman & Iya \\
\hline Klik Menu Data Wisata & Iya \\
\hline Klik Menu Data Penginapan & Iya \\
\hline Klik Menu Data Tepat Makan & Iya \\
\hline Klik Menu Jenis Wisata & Iya \\
\hline Klik Menu Jenis Penginapan & Iya \\
\hline Klik Menu Wilayah Negara & Iya \\
\hline Klik Menu Wilayah Provinsi & Iya \\
\hline Klik Menu Wilayah Kabupaten & Iya \\
\hline Klik Menu Wilayah Kecamatan & Iya \\
\hline Klik Menu Wilayah Kelurahan & Iya \\
\hline Klik Menu Wilayah Dusun & Iya \\
\hline $\begin{array}{l}\text { Klik Menu Laporan Tempat } \\
\text { Wisata }\end{array}$ & Iya \\
\hline $\begin{array}{l}\text { Klik Menu Laporan } \\
\text { Penginapan }\end{array}$ & Iya \\
\hline $\begin{array}{l}\text { Klik Menu Laporan Tempat } \\
\text { Makan }\end{array}$ & Iya \\
\hline $\begin{array}{l}\text { Klik Menu Laporan Transaksi } \\
\text { Tiket }\end{array}$ & Iya \\
\hline Klik Tombol Tambah Data & Iya \\
\hline Klik Tombol Edit Data & Iya \\
\hline Klik Tombol Delete Data & Iya \\
\hline
\end{tabular}




\begin{tabular}{|l|c|c|}
\hline Filter Pencarian & Iya & \\
\hline Klik Menu Logout & Iya & \\
\hline \multicolumn{2}{|l|}{ Kasus Dan Hasil Uji (Data Tidak Normal) } \\
\hline Form Data Input Kosong & Iya & \\
\hline $\begin{array}{l}\text { Form Data Input Profile } \\
\text { Kosong }\end{array}$ & Iya & \\
\hline
\end{tabular}

Setelah pengujian blackbox selesai kemudian dilanjutkan dengan pengujian running time pada aplikasi dan sistem, hasil pengujian diperoleh rata-rata waktu yang dibutuhkan untuk menyelesaikan setiap proses adalah 479ms. Proses login merupakan proses yang paling lama dieksekusi. Hal ini terjadi karena sebelum melakukan proses autentikasi, password dienkripsi menggunakan metode SHA1. Pengujian running time pada aplikasi E-Ticket mobile dapat dilihat pada tabel 4 .

Tabel 4. Pengujian Running Time E-Ticket Mobile

\begin{tabular}{|c|l|c|c|c|c|}
\hline No & \multicolumn{1}{|c|}{ TASK } & $\Delta \mathbf{t 1}$ & $\Delta \mathbf{t 2}$ & $\Delta \mathbf{t 3}$ & $\overline{\mathbf{x}}$ \\
\hline 1 & Menu Login & 495 & 528 & 469 & 497 \\
\hline 2 & Menu Home & 242 & 236 & 234 & 237 \\
\hline 3 & $\begin{array}{l}\text { Menu Lihat } \\
\text { Tiket }\end{array}$ & 353 & 385 & 447 & 395 \\
\hline 4 & $\begin{array}{l}\text { Menu Print } \\
\text { Tiket }\end{array}$ & 189 & 277 & 215 & 294 \\
\hline 5 & $\begin{array}{l}\text { Menu } \\
\text { Pengumuman }\end{array}$ & 301 & 311 & 337 & 306 \\
\hline 7 & $\begin{array}{l}\text { Menu About } \\
\text { Menu Option }\end{array}$ & 215 & 206 & 266 & 229 \\
\hline
\end{tabular}

\begin{tabular}{|c|c|c|c|c|c|}
\hline No & TASK & & & & \\
\hline 9 & Menu Logout & 383 & 386 & 344 & 371 \\
\hline
\end{tabular}

Untuk pengujian running time pada Sistem Informasi Pariwisata dapat dilihat pada tabel 5.

Table 5. Pengujian Running Time SI Pariwisata

\begin{tabular}{|c|c|c|c|c|c|}
\hline No & TASK & $\Delta \mathbf{t 1}$ & $\Delta \mathbf{t} 2$ & $\Delta \mathrm{t} 3$ & $\overline{\mathbf{x}}$ \\
\hline 1 & Menu Login & 641 & 653 & 667 & 652 \\
\hline 2 & $\begin{array}{l}\text { Menu } \\
\text { Dashboard }\end{array}$ & 212 & 219 & 217 & 219 \\
\hline 3 & $\begin{array}{l}\text { Menu } \\
\text { Pengelola }\end{array}$ & 154 & 233 & 204 & 197 \\
\hline 4 & $\begin{array}{l}\text { Menu Hak } \\
\text { Akses }\end{array}$ & 363 & 305 & 282 & 317 \\
\hline 5 & $\begin{array}{l}\text { Menu } \\
\text { Pengumuman }\end{array}$ & 495 & 528 & 469 & 497 \\
\hline 6 & $\begin{array}{l}\text { Menu Data } \\
\text { Wisata }\end{array}$ & 215 & 206 & 266 & 229 \\
\hline 7 & $\begin{array}{l}\text { Menu Data } \\
\text { Penginapan }\end{array}$ & 353 & 385 & 447 & 395 \\
\hline 8 & $\begin{array}{l}\text { Menu Tempat } \\
\text { Makan }\end{array}$ & 189 & 277 & 415 & 294 \\
\hline 9 & $\begin{array}{l}\text { Menu Jenis } \\
\text { Wisata }\end{array}$ & 283 & 286 & 244 & 271 \\
\hline 10 & $\begin{array}{l}\text { Menu Jenis } \\
\text { Penginapan }\end{array}$ & 304 & 237 & 307 & 283 \\
\hline 11 & $\begin{array}{l}\text { Menu Wilayah } \\
\text { Provinsi }\end{array}$ & 157 & 196 & 157 & 170 \\
\hline 12 & Menu Wilayah & 301 & 287 & 251 & 298 \\
\hline
\end{tabular}




\begin{tabular}{|c|c|c|c|c|c|}
\hline No & TASK & $\Delta t 1$ & $\Delta t 2$ & $\Delta t 3$ & $\overline{\mathbf{x}}$ \\
\hline & Kabupaten & & & & \\
\hline 13 & $\begin{array}{l}\text { Menu Wilayah } \\
\text { Kecamatan }\end{array}$ & 370 & 210 & 239 & 273 \\
\hline 14 & $\begin{array}{l}\text { Menu Wilayah } \\
\text { Kelurahan }\end{array}$ & 289 & 277 & 315 & 294 \\
\hline 15 & $\begin{array}{l}\text { Menu Wilayah } \\
\text { Dusun }\end{array}$ & 341 & 311 & 367 & 306 \\
\hline 16 & $\begin{array}{l}\text { Laporan } \\
\text { Tempat Wisata }\end{array}$ & 154 & 233 & 204 & 197 \\
\hline 17 & $\begin{array}{l}\text { Laporan } \\
\text { Tempat } \\
\text { Peginapan }\end{array}$ & 853 & 185 & 147 & 395 \\
\hline 18 & $\begin{array}{l}\text { Laporan } \\
\text { Tempat Makan }\end{array}$ & 189 & 277 & 415 & 294 \\
\hline 19 & $\begin{array}{l}\text { Laporan } \\
\text { Transaksi Tiket }\end{array}$ & 341 & 411 & 367 & 376 \\
\hline 20 & $\begin{array}{l}\text { Notifikasi } \\
\text { Perubahan } \\
\text { Data }\end{array}$ & 215 & 206 & 266 & 229 \\
\hline 21 & Menu Logout & 154 & 233 & 204 & 197 \\
\hline
\end{tabular}

Senjutnya pada pengujian Respon Pengguna didapat beberapa hasil analisis sebagai berikut 1) Pada pertanyaan pertama mendapatkan persentase sebesar $94 \%$ dari bobot maksimal, yang menunjukan tata letak menu serta isi pada setiap menu pada sistem sudah rapi; 2) Pertanyaan kedua mendapatkan nilai persentase 92\% dari bobot maksimal, berarti menu-menu yang ada dalam sistem mudah dipahami; 3). Pertanyaan ketiga mendapatkan persentase sebesar 96\% dari bobot maksimal, yang menunjukan fitur-fitur dalam sistem berjalan dengan baik; 4) Pada pertanyaan keempat mendapatkan persentase sebesar $94 \%$ dari bobot maksimal, menunjukan informasi yang dihasilkan sistem sudah lengkap. Pengujian menggunakan Intrument Respon Pengguna untuk setiap pertanyaan mewakili 5 kriteria. Pengujian ini dilakukan dengan memilih 10 petugas tempat wisata yang berbeda sebagai responden. Berikut adalah hasil pengujian Respon Pengguna dapat dilihat pada table 6 .

Tabel 6. Hasil Pengujian Respon Pengguna

\begin{tabular}{|c|c|c|c|c|c|c|}
\hline \multirow{2}{*}{ No } & \multirow{2}{*}{ Kriteria } & \multicolumn{5}{|c|}{ Skor Penilaian } \\
\hline & & SB & B & C & KB & SKB \\
\hline \multicolumn{7}{|c|}{ PERTANYAAN 1} \\
\hline 1 & $\begin{array}{l}\text { Sistem informasi } \\
\text { sangat mudah diakses } \\
\text { dari semua } \\
\text { komputer/mobile }\end{array}$ & 8 & 2 & & & \\
\hline 2 & $\begin{array}{l}\text { Input data dapat } \\
\text { dilakukan dengan } \\
\text { cepat }\end{array}$ & 10 & & & & \\
\hline 3 & $\begin{array}{l}\text { Data yang diperlukan } \\
\text { bisa didapatkan } \\
\text { dengan mudah }\end{array}$ & 9 & 1 & & & \\
\hline 4 & $\begin{array}{l}\text { Laporan/report dapat } \\
\text { dihasilkan dengan } \\
\text { mudah dan sesuai } \\
\text { kebutuhan }\end{array}$ & 10 & & & & \\
\hline 5 & $\begin{array}{l}\text { Sistem dapat } \\
\text { menghasilkan laporan } \\
\text { yang fleksibel }\end{array}$ & 10 & & & & \\
\hline \multicolumn{7}{|c|}{ PERTANYAAN 2} \\
\hline 6 & $\begin{array}{l}\text { Sistem yang ada } \\
\text { mudah dipahami }\end{array}$ & 9 & 1 & & & \\
\hline 7 & $\begin{array}{l}\text { Sistem yang ada } \\
\text { mudah digunakan }\end{array}$ & 9 & 1 & & & \\
\hline 8 & $\begin{array}{l}\text { Sistem yang ada } \\
\text { mudah dipelajari }\end{array}$ & 10 & & & & \\
\hline
\end{tabular}




\begin{tabular}{|c|c|c|c|c|c|c|}
\hline \multirow{2}{*}{ No } & \multirow{2}{*}{ Kriteria } & \multicolumn{5}{|c|}{ Skor Penilaian } \\
\hline & & SB & B & $\mathbf{C}$ & KB & SKB \\
\hline 9 & $\begin{array}{l}\text { Informasi yang } \\
\text { disajikan jelas untuk } \\
\text { dimengerti }\end{array}$ & 10 & & & & \\
\hline 10 & $\begin{array}{l}\text { Tata letak tampilan / } \\
\text { display mudah } \\
\text { dikenali/dilihat }\end{array}$ & 8 & 2 & & & \\
\hline \multicolumn{7}{|c|}{ PERTANYAAN 3} \\
\hline 11 & $\begin{array}{l}\text { Informasi yang } \\
\text { diberikan sesuai dan } \\
\text { akurat }\end{array}$ & 9 & 1 & & & \\
\hline 12 & $\begin{array}{l}\text { Data yang anda input } \\
\text { aman dari orang yang } \\
\text { tidak berhak } \\
\text { mengakses }\end{array}$ & 10 & & & & \\
\hline 13 & $\begin{array}{l}\text { Sistem mempunyai } \\
\text { backup data yang } \\
\text { bagus }\end{array}$ & 9 & 1 & & & \\
\hline 14 & $\begin{array}{l}\text { Data anda tidak hilang } \\
\text { meskipun listrik mati } \\
\text { mendadak }\end{array}$ & 10 & & & & \\
\hline 15 & $\begin{array}{l}\text { Data anda tidak hilang } \\
\text { meskipun komputer } \\
\text { anda rusak }\end{array}$ & 10 & & & & \\
\hline \multicolumn{7}{|c|}{ PERTANYAAN 4} \\
\hline 16 & $\begin{array}{l}\text { Aplikasi e-ticket } \\
\text { jarang not responding }\end{array}$ & 9 & 1 & & & \\
\hline 17 & $\begin{array}{l}\text { Sistem informasi } \\
\text { jarang not responding }\end{array}$ & 10 & & & & \\
\hline 18 & $\begin{array}{l}\text { Anda puas dengan } \\
\text { kelengkapan data yang } \\
\text { disediakan oleh sistem } \\
\text { informasi tersebut }\end{array}$ & 8 & 2 & & & \\
\hline
\end{tabular}

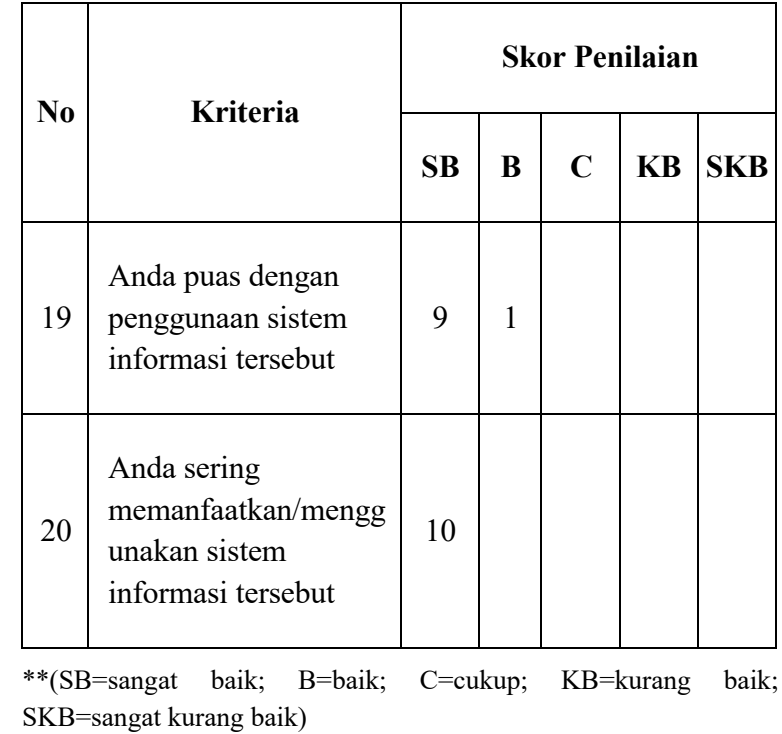

\section{KESIMPULAN}

\section{A. Kesimpulan}

Berdasarkan hasil penelitian dan pengujian dapat disimpulkan: 1) Prototype aplikasi E-Ticket Mobile yang telah dikembangkan memiliki fitur sesuai dengan hasil analisis fitur yaitu 9 fitur menu utama pada aplikasi; 2) Prototipe System Informasi Pariwisata yang telah dikembangkan memiliki fitur sesuai dengan hasil analisis fitur yaitu, 21 fitur menu utama pada sistem; 3) Hasil pengujian blackbox seluruh fitur yang diterapkan telah menghasilkan output sesuai yang diharapkan; 4) Pada pengujian running time diperoleh rata-rata waktu yang dibutuhkan oleh apikasi serta sistem untuk menyelesaikan setiap proses adalah $479 \mathrm{~ms}$; 5) Hasil analisis pengujian Respon Pengguna menyimpulkan, tata letak menu serta isi setiap menu dalam sistem sudah rapi dan mudah dipahami. Fitur-fitur dalam sistem sudah berjalan dengan baik.

\section{B. Saran}

Sistem ini masih memiliki keterbatasan terkait dengan kebijakan pada daerah tempat wisata yang berbeda-beda. Peneliti berikutnya diharapkan dapat mengembangkan sistem yang dapat menyesuaikan dengan kebijakan untuk objek wisata di kabupaten lain, agar nantinya Sistem Informasi Pariwisata yang terintegrasi dengan aplikasi E-Ticket ini tidak hanya dapat digunakan untuk kabupaten Karangasem saja. 
Dengan adanya penyesuaian terhadap kebijakan di pengembangan selanjutnya aplikasi juga dapat digunakan oleh Dinas Pariwisata di kabupaten yang lainnya.

\section{DAFTAR PUSTAKA}

[1] Hadiwijoyo and S. Suryo, "Perencanaan Pariwisata Perdesaan Berbasis Masyrakat." Graha Ilmu, Yogyakarta, 2017.

[2] H. Farudin, "Pembangunan Berwawasan Budaya." Departemen Kebudayaan dan Pariwisata, Jakarta, 2016.

[3] M. Sabri and D. P. Sari, "An Analysis on Tourism Potency and the Community Readiness in Developing Berancah as a Tourism Village," vol. 298, no. iCAST 2018, pp. 32-35, 2020.

[4] F. Maurer and S. Martel, "Extreme Programming," no. February, 2016.

[5] C. Poole, J. W. Huisman, and I. Technologies, "Using Extreme Programming in a Maintenance Environment," no. December, 2017.

[6] K. Beck, "Change with Extreme Programming," no. c, pp. 70-77, 2019.

[7] K. Stapel, D. Lübke, and E. Knauss, "Best Practices in eXtreme Programming Course Design,” pp. 769-775, 2017.

[8] P. Sharma and N. Hasteer, "Analysis of Linear Sequential and Extreme Programming Development Methodology for a Gaming Application,”pp. 1916-1920, 2016.

[9] A. Wichmann, R. Maschotta, F. Bedini, J. Sven, and A. Zimmermann, "A UML Profile for the Specification of System Architecture Variants Supporting Design Space Exploration and
Optimization," no. Modelsward, pp. 418-426, 2017.

[10] A. Verma, A. Khatana, and S. Chaudhary, "A Comparative Study of Black Box Testing and White Box Testing International Journal of Computer Sciences and Engineering Open Access A Comparative Study of Black Box Testing and White Box Testing," no. July, 2019. 